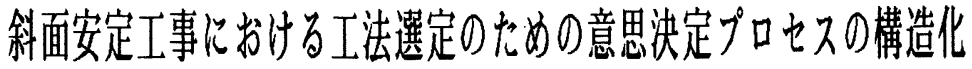

Decision Making Process of Construction Method for Stability of Slope

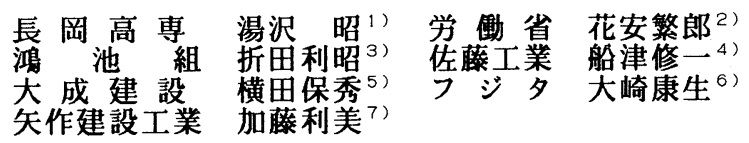

By Akira Yuzawa, Shigeo Hanayasu, Toshiaki Orita, Shuichi Funatu, Yasuhide Yokota, Yasuo Ohsaki and Toshimi Katoh

建設工事では、計画から維持管理における各段階において適切な意思決定が要求 されるが、これらはill一構造問題であり、意思決定のシステム化が困難な分野の 1 つである。これは建設工事が自然条件の中で実施され、その自然条件の設定が非常 に困難であり、かつ不確実性が大きいところに起因する。本研究は、各種建設工事 における意思決定問題に関守る調查とその構造分析、また具体的な事例として、斜 面安定工事を取り上げ、対策工の特性分析、地山の状況と工事の㻴境に関する要因 の抽出と整理、さらには工法選定における意思決定プロセスについての検討を行う ことを目的としている。

【キーワード】意思決定、斜面安定工事、施工計画

\section{1. 粕言}

人間の意思決定プロセスを段階的に考えると、(1) 問題の発見的段階、(2)設計段階、および(3)選択段 階に分けることができる。発見的段階とは、問題の 発見と環境情報の収集のプロセスであり、設計段階 とは代替案の探索の分析であり、最後の選択段階と は代替案の選択プロセスを意味している。この3段 階の意思決定プロセスの諸段階が良く構造化された 問題が、いわゆる well-構造問題であり、各段階に おいて統計解析や O Rの適用により、最適な意思決 定ルールを特定化することが可能である。これに対 し、意思決定の各段階において構造化が困難な問題 がill-構造問題であり、この種の問題においては、 意思決定者である人間の果たす役割が大きく、個人 の洞察力や過去の経験、価値判断が意思決定のため の重要な要素となる。従って、いかにして人間の持 つ発見的能力 (heuristics) をシステム化するかが 課題となるが、人工知能やエキスパートシステムに
代表されるように、コンピュータの発達と知識工学 の発展が相まって今後システム化がさらに進むむの と思われる。

建設工事は、各段階において適切な意思決定が要 求されるが、これらは典型的なill-構造問題であり、 意思決定のシステム化が困難な分野の 1 つである。 これは建設工事があらゆる自然条件の中で実施され、 その自然条件の設定が非常に困難であり、かつ不確 実性が大きい所に起因する。徉って、well-構造問 題に近づけるためには、不確実性の削隇と意思決定 プロセスの明確化が必要とされる。

本研究は、建設工事に関する意思決定事例を通し て、要因の設定方法と意思決定ルールの分析、さら には具体的事例として斜面安定工事を取り上げ、対 策工の特性、地山の状況、工事の環境に対する考虑 すべき要因の抽出と整理（問題の発見的段階と設計 段階）、工法選択における意思決定プロセスの構造 を明確にする（選択段階）ことを目的とする。

\section{2. 建設工事における意思決定の問題点}

意思決定とは、種々の代替案 (選択肢) の中から それぞれの結果を予測して、予め決められた選考基 準に徉って最良な代替案を採択することである。図 - 1 は、本研究で対象としている斜面安定工事の工 
法選択問題における一般的な意思決定のプロセスを 整理したものである。本研究では、意思決定のプロ セスを2段階に分けて考えている。第 1 段階は、代 替案の選別であり、第2 段階は代替案の選択のプロ セスである。すなわち、第 1 段階ではある基準を満 足しない代替案を除去し（あるいはある基準を満足 する代替案を残す）、実施可能な選択肢集合の決定 であり、第2段階ではそれらの集合の中からある基 準に従って最良な案を選択することになる。ここで 問題となるのが第 1 段階においては、選別のルール の設定をどのように行うかであり、第2 段階では選 択の方法の決定である。

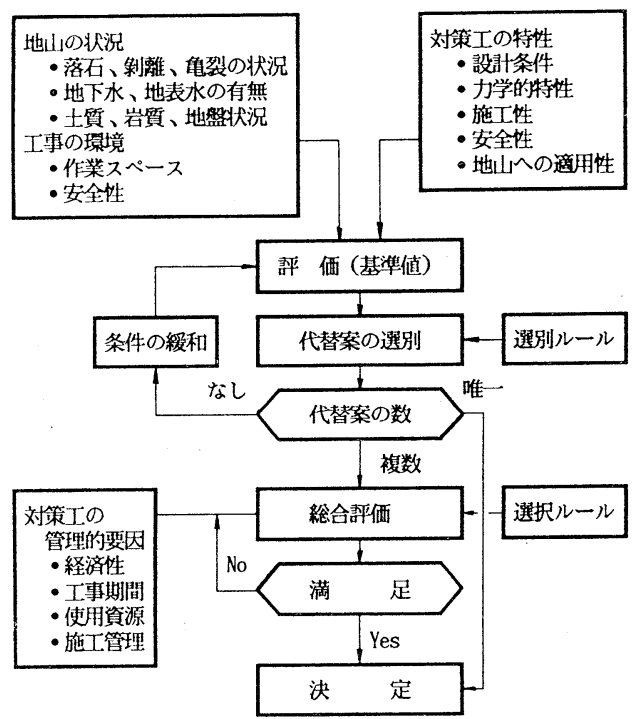

図ー 1 斜面安定工事における意思決定プロセス

表ー 1 は、意思決定のためのルールを整理したも のであり、大きく非補償型と補償型に分類される ${ }^{1)} 。$ これらのルールを適用するに当たっては、全ての選 択肢は多属性表現されていることを前提としている。 この多属性表現とは、各選択肢が複数の同じ属性 （または要因、評価項目）（例えば、工費、工事期 間、地質、斜面勾配等）で記述されていることを意 味している。ここで非補償型とは、複数の属性を同 時に考慮するのではなく、選択肢間である属性に着 目して 1 つづつ比較を行うことにより代替案の選択 を段階的に行い、また補償型は複数の属性を同時に 評価することにより最す望ましい代替案を選択する
表- 1 意思決定ルール

\begin{tabular}{|c|c|}
\hline 補 & 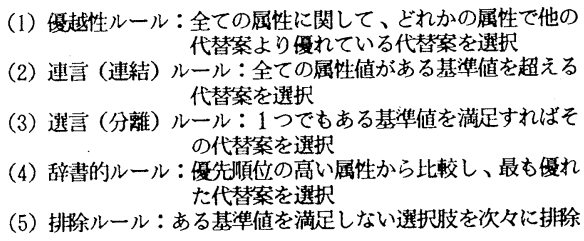 \\
\hline & 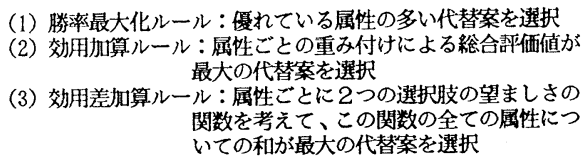 \\
\hline
\end{tabular}

方法である。したがって、非補儐型のルールでは、 必ずしす唯一の選択肢が選ばれるとは限らない。

これらの選択方法はそのモデルの特性上、全ての 要因値（または評価値）があらかじめ決定されてい る必要性があるが、このことは必ずしも容易なこと ではない。すなわち、要因によりそのデータの信頼 性が大きく異なっているのが通常である。

図一2は、斜面安定工事における主な要因をその 特性に基づいて整理したものである。比尺度とは、 費用（円）や工期（日）のように一定の単位があり、 容易に定量化が可能な要因である。間隔尺度は必ず しも基準となる零点はないが、比尺度と同様な取扱 いが可能な要因である。序数尺度は、その值の順序 は意味をむつが、数值そのものの意味は無いような 要因、例えば落石の可能性が「1：非常に可能性有 り、2:やや可能性有り、3: 可能性なし」と表現 される場合には序数尺度となる。しかし、落石の可 能性を力学的な観点から表現するとした場合には、 比尺度あるいは間隔尺度としての表現む可能ではあ る。最後に名義尺度とは、土質の区分 ( 1 ：粘性土、 2 : 砂質土、 3 : 軟岩) や地形、地質構造等に見ら

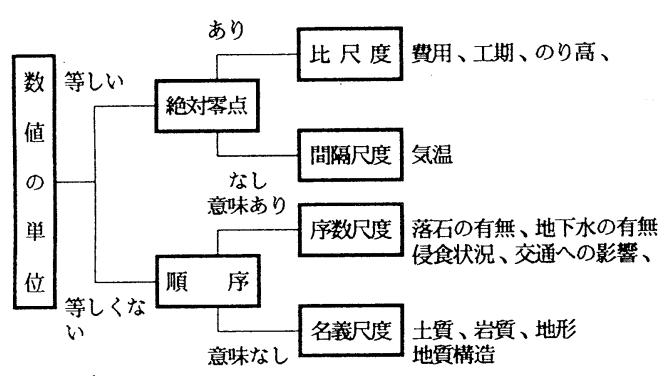

図一2 データの種類 
れるようにその数值が全く意味を持たないような要 因である。

このように取り报う要因により、数値の持つ意味 や信頼性は大きく異なるが、比尺度や間隔尺度は、 統計学的に取り扱うことが可能であるため、意思決 定においても比較的構造化がし易い。しかし、序数 尺度や名義尺度の要因の決定には、個人の経験や価 值判断が重要な要素となるため、決定された值は多 少とむあいまい性（fuzziness）を含むことになる。 徉って、何らかの方法により序数尺度や名義尺度を 間隔尺度へ変換させる必要がある。

以下に、序数尺度の特徵と間隔尺度への変換方法 の例について述べる。ただし、これらの各データは 個人だけでもその值を設定することは可能であるが、 本論文においては複数の意思決定者により決定され るむのとする。

\section{(1) OX法}

○×法は最む良く用いられているむのの 1 つであ り、この変形法に○×点数法がある。これは○や $\Delta 、$ メにある点数を割り当てることにより、間隔尺度へ の変換を図る方法である。OX法では、要因毎にあ る条件 (基準) を満足している度合いによって、○、 $\triangle 、$ 等を全ての選択肢に当てはめることになるが、 その決定に当たっては十分な協議が必要である。

\section{（2） n段階評価法}

$\mathrm{n}$ 段階評価法は、前述したように「1：非常に可 能性有り、2:やや可能性有り、3: 可能性なし」 の例のように要因の値を $\mathrm{n}$ 段階に分類する方法であ り、一般的には5 段階や7段階が採用されている。 このようにして決定された値を持って、間隔尺度と するのが $\mathrm{n}$ 段階評価法である。

\section{（3）一対比較法}

一対比較法は、要因毎に選択肢を 1 ペアづつ比較 し、全ての一対比較データより各選択肢の相対的な 値を推定する方法である（組み合わせの回数は、 $n$ (n-1)/2）。推定方法としては多次元尺度法によるむ のや、固有值法等が代表的であるが、固有値法によ る研究事例が近年多く見られる。これは階層的意思 決定法 (AHP：Analytic Hierarchy Process) ${ }^{2)}$ と呼ばれており、建設工事においてもいくつかの研 究事例が報告されている3)。しかし、この方法は選 択肢の数が多くなると、その組み合わせ回数が指数
的に增大する。

\section{（4）順序付け法}

順序付け法は、各選択肢間に順位付けを行うもの で、基本的には $\mathrm{n}$ 段階評価法と同種であるが、その 值は、単なる選択肢間の順序を記述しているだけで あるため、その順番をむって間隔尺度と見なすには 危険がある。通常用いられている方法としては、同 一順序の回答のみのクロス集計を行うといった、便 宜的な方法が採用されている場合が多い。

本節では、複数の意思決定者から得られた順序デ 一タを用いて、序数尺度から間隔尺度への変換方法 について述べる。斉藤は4、集計された順序データ を要因間の一対比較により得られるとデータと同一 形式と見なすことにより、前述した A H P 手法の考 え方を適用し、序列尺度から間隔尺度への変換を図 っている。すなわち、はじめに順序データから式(1) ような行列を作成する。

$$
X i j=\sum_{k=1}^{S} X i j k \quad(i, j=1,2, \cdots, m, i \neq j)
$$

$\mathrm{Xijk}$ ：個人kにとって、選択肢 $\mathrm{i}$ が選択肢 $\mathrm{j}$ より順位が高い場合は 1 、それ以外は 0 $\mathrm{m}$ ：選択肢の数、 $\mathrm{s}$ : 意思決定者の数

式(1）から明らかなように、Xij=s の場合は、全

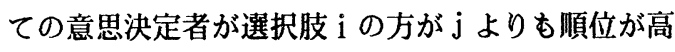
いと回答しており、逆に Xij=0 場合には、選択肢 jの方が i に比較して順位が高いと判断しているこ とになる。式(1) のXは選好強度行列と呼ばれてお り、選択肢 $\mathrm{i} か ゙ \mathrm{j}$ に比較してどの程度重要であるか を表すむのである。次に式(1）を式(2）のように変 換する。

$$
\mathrm{Aij}=\mathrm{Xij} / \mathrm{Xji}
$$

したがって、Aji=1/Aijとなる。式(2）より得 られる行列に、前述したA H P の固有値法を適用す ることにより選択肢 $\mathrm{i}$ の相対的な重み (Wi) を計 算し、その值を間隔尺度とする。すなわち、

$$
A i j=W i / W j
$$

という関係にある。この方法においては、複数の意 思決定者から得られる順序データを比率データと見 なしているが、ここでは比率データではなく間隔デ 一タとすると、式(2),(3)は次のようになる5)。

$$
A i j=X i j-X j i=W i-W j
$$


ここで式(4) は、推移性を満足するすのと仮定する。

$$
A i j=A i k+A k j
$$

一般に意思決定者の判断は推移性を満足しないので、 問題としては意思決定者の行った判断に最む近い推 移性を満足する選好強度行列 $(\mathrm{Pi}=\mathrm{j}=\mathrm{W}-\mathrm{W} \mathrm{j})$ を求める 必要がある。ここで次のような関数を定義する。

$$
D(A 、 P)=\sum_{i, j}(A i j-P i j)^{2} \ldots
$$

式(6) より

$$
\mathrm{D}=\Sigma(\mathrm{Aij}-\mathrm{Wi}+\mathrm{Wj})^{2}
$$

となる。ここで問題は、式(7) の最小化問題を解く ことになるため、式 (7) をWiで偏微分し、0とお くことにより、次のようになる。

$$
\sum_{\mathrm{i}} \mathrm{A} i \mathrm{j}-\sum_{\mathrm{i}} \mathrm{Wi}+\mathrm{mWj}=0
$$

式(8)において選択肢の重み (Wi) は、間隔デー夕 であるから、原点の位置には任意性がある。ここで は平均が 0 となるようなWの值を求めると、

$$
\mathrm{Wj}=-\sum_{\mathrm{i}} \mathrm{Aij} / \mathrm{m}=\sum_{\mathrm{j}} \mathrm{Aj} \mathrm{i} / \mathrm{m} \cdots
$$

式(9)から求まったWjが、複数の意思決定者から得 られた選択肢の順位データを元に、各選択肢の相対 的な重要性を間隔尺度に変換したものである。

\section{3. 建設工事における意思決定事例}

意思決定において最む重要な課題は、要因の選定、 それらの要因値の決定、意思決定のための構造化、 および代替案選択における意思決定ルールの明確化 である。本章においては、建設工事における意思決 定の事例を通して、要因值の設定方法と意思決定ル ールについて述べる。

中村は6)、小口径推進における工法選定基準に関し、 以下のような意思決定プロセスに基づいて工法の選 定を行っている。その意思決定フローは、「設計条 件の入力」 $\rightarrow$ 「適用可能工法の特性把握」 $\rightarrow$ 「設計 条件による適用可能工法の絞り运み」 $\rightarrow$ 「経済評価 による総合評価」「「工法の選択」となっている。 ここで適用可能工法の絞り込みは、表ー 1 に示した 排除ルールを適用している。すなわち、ある条件を 満足しない工法を次々に排除し、残った工法に対し て経済比較を行い、最終的な工法を選択している。 ただし、各要因の評価としては○×法を採用し、ま た各要因の重要性としては言語による万法を採用し
ている（必要、不要、ある条件の時は必要等）。そ して最終的には、Oメと要因の重要性を考虑して工 法の選択を行っている。したがって、総合評価の方 法としては、辞書的ルールの適用である。

吉川・山田・日吉は7)、路上表層再生工法の選定 問題に関して、「工法の分類」 $\rightarrow$ 「要因の設定」 $\rightarrow$ 「要因值の決定」 $\rightarrow$ 「法の総合評価」という流れ で工法の選定を行っている。ここで「要因値の決定」 としては、各要因の物理的な值（針入度、軟化点、 伸度、空隙率等)を 4 つの区分に分割し、各々の区 分に対して 1 から 4 の数值を当てはめている。そし て最終的に各要因毎の評価値を合計して、総合評価 を行っている。この事例の特徽としては、各要因の 重要度の差を考虑しなくともすむように、各要因を 4 つの区分に分割する際、各要因の重みが等しくな るように区分している。徉って、要因値としては間 隔尺度、総合評価の方法は効用加算ルールを適用し ている。この場合、各要因の物理的な值を間隔尺度 へ変換することは必ずしも容易なことではなく、何 らかの科学的な方法により区分の分割を行う必要が ある。

適切な要因の分割と各区分に対する重みの推定手 法として、良く用いられるものの 1 つに多変量解析 の適用がある。すなわち、各要因が比尺度や間隔尺 度の場合には、判別分析の適用が可能であり、また 序数尺度や名義尺度の場合には数量化理論第 2 類が 挙げられる。佐藤・八谷・林は ${ }^{8)}$ 、空港舗装の修繥 計画に際して、数量化理論第 2 類の適用を図り、修 繕の必要性の有無の意思決定を検討している。そこ では、空港舗装の共用性を表す評価式を作成するた めに、複数の要因（わだちぼれ、平坦性、クラック 等) と修繥の必要性（必要有り、必要なし）との関 係から数量化理論第 2 類の適用を図り、修繥意思決 定のための総合評価式を提案している。意思決定プ ロセスとしては、「要因の設定」 $\rightarrow$ 「数量化理論第 2 類の適用」 $\rightarrow$ 「要因の絞り込み」 $\rightarrow$ 「総合評価式 の作成」 $\rightarrow$ 「舗装状況の総合評価点」 $\rightarrow$ 「舗装の修 繕の必要性の検討」となっている。従って、要因の 種類としては序数尺度と名義尺度であり、また意思 決定ルールは効用加算ルールを用いている。しかし、 効用加算ルールの場合には、ある要因の値が極端な 場合でむ他の要因の值により互いに打ち消し合うこ 
とによって不都合が生じることがある。そのような 問題を回避するため、要因がある值を超過する（小 さすぎる）場合には、その要因の值のみで選択肢の 削除を行っている（排除ルールの適用）。このよう に総合評価においては、複数の意思決定ルールを適 用している点が特徵的である。

奥園は ${ }^{9)}$ は、のり面保護工法の選定プロセスに関 する研究を行っており、特に斜面安定工法の適用に 当たっては、安定解析が困難であるため経験工学に 依存するところが大きいとしている。具体的には、 意思決定のため考虑すべき要因の分析と、のり面保 護工法選定のためのフロー図を提案している。この 研究における意思決定基準としては、選言 (分離) ルールと排除ルールの併用により、対策工の選定プ ロセスを説明しており、本研究との類似点が非常に 多い研究ですある。

上述した事例はいずれも要因の値をあらかじめ設 定し、その結果を用いて最終的な意思決定を行って いるが、要因値の設定を行うことは必ずしも容易な ことではない。すなわち、要因値として人間の感覚 值に頼らざるを得ない要素があり、数値化が困難な 場合がある。このような場合の意思決定のための方 法として、前述したようにAHP手法がある。吉井 ・林は3)、建設工事における工法選定問題に A H P 手法を適用し、その有効性を検討している。意思決 定のプロセスとしては、「実行可能な対策工の抽出」 $\rightarrow$ 「評価要因の階層化」 $\rightarrow$ 「A H P 手法による分析」 $\rightarrow$ 「総合評価」 $\rightarrow$ 「工法選択」となっている。この 手法の特徵は、各要因の選択肢別の值を選択肢間の 一対比較より理論的に求めるところにあり、その值 は相対的なものであるため、間隔尺度と見なすこと ができる。また、意思決定ルールとしては効用加算 ルールを採用している。しかし、「実行可能な対策 工の抽出」に当たっては、排除ルールを適用し、実 行可能対策工の絞り込みを行っている。

このように意思決定プロセスにおいては、共通し ている点が多々あるが、要因の設定方法や意思決定 ルールはその問題により異なっていることが分かる。 しかし、一般的には図ー1に示したように選別ルー ルと選択ルールの使い分け、または両者の併用（段 階的に適用）により、最終的な意思決定を行ってい る点については共通したものである。

\section{4. 斜面安定工事の意思決定フロセスの構造化}

本章においては、実際の斜面安定工事の事例を通 して工法選定における考虑すべき要因の特定化とそ の意思決定プロセスの構造化を図る。なお、工事の 事例の収集に当たっては、建設マネジメント委員会 C 2小委員会の計画・管理技法分科会所属の建設会 社 7 社の協力を得て、有効数 146 のサンプルを得 た。またサンプルの収集には、各企業の斜面安定工 事に携わっている設計担当者と工事経験者を対象と 乙（平成 4 年 12 月に実施）、調査用紙に必要事項 を記入してもらう方法を採用した。なお、調査項目 は、表ー2に示すように記入者の所属や経験年数、 施工場所、工法等の工事の概要と施工位置の地山の 状況（落石、地下水、侵食、勾配等）と工事の環境 （交通への影響、作業スペース、施工管理、資源の 制約等）、それに各種の工法を設計または施工する 際に考慮すべき要因の重要性についても質問を行っ ている。なお、要因の設定には関連文献の調査、専 門家へのヒアリングとブレーンストーミング等を行 い決定した。またこの調查の目的は、斜面安定工事 のための工法を選択するシステムを構筑するのが目 的ではなく、あくまでむ工法選択における意思決定 プロセスを明確にすることである。

表 -2 調査項目

\begin{tabular}{|c|c|}
\hline 個人属性 & 所属、経験年数 \\
\hline 工事の概要 & $\begin{array}{l}\text { 工種、施工場所、発注主 } \\
\text { 工法の種類 (表-4参照) } \\
\text { 工法の決定者 } \\
\text { 地山の状況 ( } 15 \text { 要因) } \\
\text { 工事の環境 ( } 17 \text { 要因) }\end{array}$ \\
\hline $\begin{array}{l}\text { 工法别の要 } \\
\text { 因の重要度 }\end{array}$ & $\begin{array}{l}\text { 大分類と小分類毎に地山の } \\
\text { 状況が } 15 \text { 要团、工事の環 } \\
\text { 境が } 18 \text { 虽因の中から重要 } \\
\text { と思われる䐓に上位 } 5 つ の \\
\text { 要因を選択 }\end{array}$ \\
\hline
\end{tabular}

\section{1 调查結果の概要}

表一 3 は、被験者の所属と工事の概要を整理した むのである。記入者の所属は、現場部門が99件と 最も多く、次いで設計部門の29件となっている。 工事の種類では、道路工事に関するむのが 52 件と 全体の $36 \%$ 占めており、宅造の 32 件（22\%） となっている。これは斜面安定工事の特性からも理 解できる。工事の発注元は、工事の種類からも分か 
表 -3 調查結果の概要

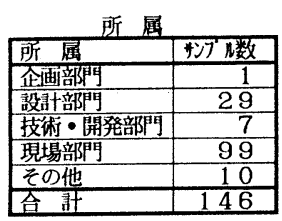

工事の発注元

\begin{tabular}{|c|c|}
\hline 発注元 & \$7 n数 \\
\hline 国 & 18 \\
\hline 都道府県 & 18 \\
\hline 市町村 & 13 \\
\hline 第三セクター & 2 \\
\hline 各種公団 & 38 \\
\hline 民聞企業 & 51 \\
\hline その他 & 6 \\
\hline 合棓 & 46 \\
\hline
\end{tabular}

工法の決定者

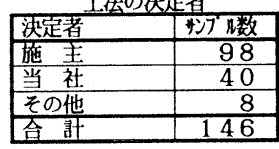

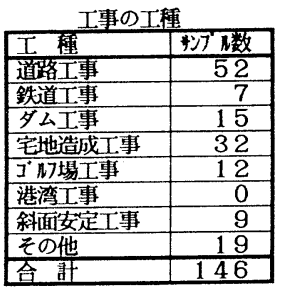

担当分野

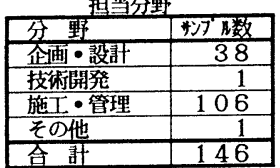

斜面安定工事の経鉃回数

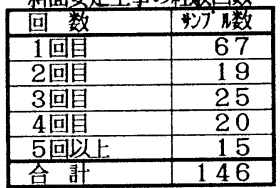

るように公団と民間企業とで全体の $61 \%$ \%占 めている。

本調查においては、斜面安定工事に採用された工 法の種類について、その大分類と小分類の番号を記 入してもらう方法を採用した（工法の分類は、表一 4の通りである）。また、各工事においては必ずし む唯一の工法のみを使用している訳ではなく、複数 の工法を組み合わせて工事を実施しているケースが 多いむのと判断し、重要と思われる順に使用した全 ての工法を記入してもらった。

表ー5は、第 1 位に挙げられた工法について、横 方向に大分類を縦方向に小分類を取り、各々の件数 を整理したものである。件数的に最も多いのが、力 学的安定工法の 54 件であり（小分類では、のり面 アンカー工法が 22 件) 、次いで被覆工法（斜面保 護工法）の 33 件、植生工法（斜面安定工法）の 3 0件となっている。表一6は、各工法の組み合わせ を整理したすのであり、単独工法のみの件数は 36 件と全体の $25 \%$ にぎず、残りの $75 \%$ は複数の 工法の組み合わせとなっていることが分かる。件数 的に多いのは、被覆工法と植生工法の組み合わせ （26 件）、力学的安定工法と被覆工法の 20 件、 力学的安定工法と吹き付け工法の 14 件となってい る。

\section{2 斜面安定工法の特性}

斜面安定工法は、その特性により工法の力学的、

表-4 斜面安定工法の大分類と小分類

\begin{tabular}{|c|c|}
\hline \multirow[t]{2}{*}{ 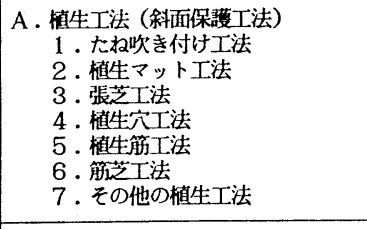 } & 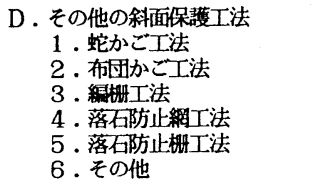 \\
\hline & \multirow[b]{2}{*}{$\begin{array}{c}\text { E. 排水工法 (斜面安定工法) } \\
1 . \text { 表面排工法 } \\
2 . \text { 地排水工法 } \\
3 . \text { 重力排水工法 } \\
4 . \text { 强制排水工法 } \\
5 . \text { その他の排工法 }\end{array}$} \\
\hline \multirow{3}{*}{ 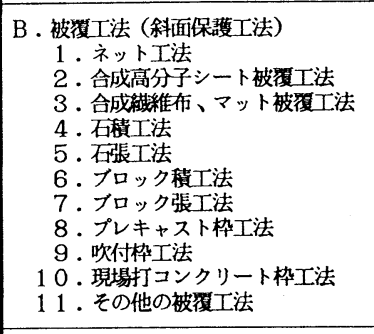 } & \\
\hline & 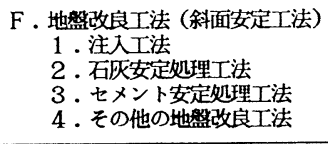 \\
\hline & \multirow[b]{2}{*}{ 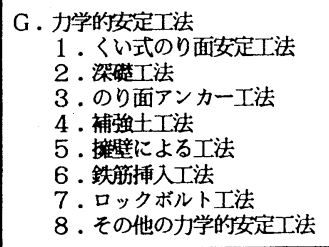 } \\
\hline 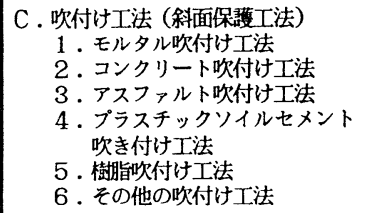 & \\
\hline
\end{tabular}

表－5 工法別の道用頻度

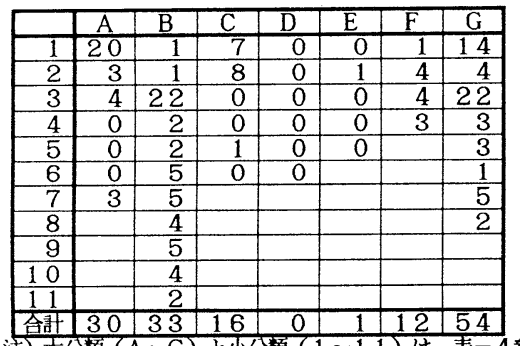

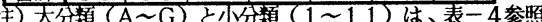

施工的特性が異なる。図一 3 は、工法の特性を現場 への適用性と工事環境の観点から整理したものであ る。当然、工法によっては該当しない項目も存在す るが、工法の選択に当たっては各工法の特性を十分 に把握しておく必要がある。

表ー7は、図一 3 に示したような特性を持つ斜面 安定工法を実際の現場に適用する場合、「地山の状 況」と「工事の環境」の観点から要因を整理し、ど のような要因を重要視するかを質問した結果を工法 別（大分類）に整理したものである。調查において は、「地山の状況」と「工事の環境」別に重要と思 われる順に要因の番号を記入してむらい、その結果 から最む重要性の高い要因の值を 1.0 、最む低い要 因を 0.0 と基準化した（順序データの間隔尺度への 変換には式(9）を用いた）。「地山の状況」を見る 
表－6 工法の組み合わせ（大分類）

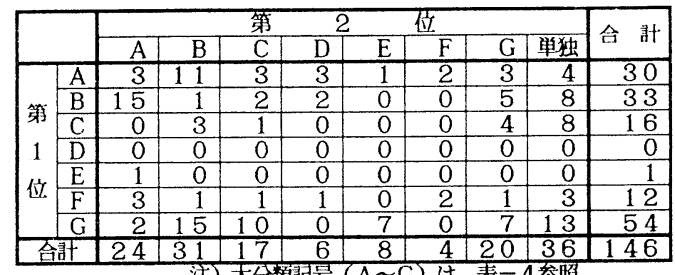

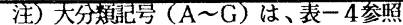

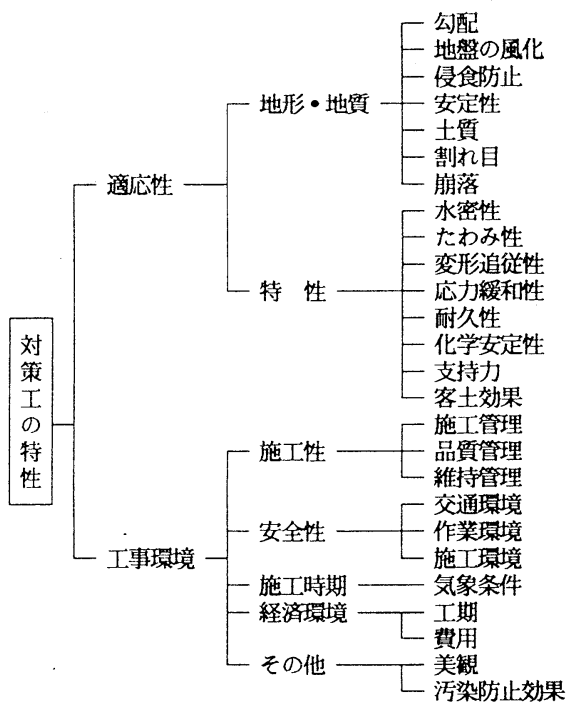

図-3 斜面安定工法の特性

と、雓面保護工法（AからD）では斜面の勾配の重 要性が他の要因に比較して高く、中でも植生工法は、 地表の土質、地表水の有無の要因が重要とされてい る。吹き付け工法は、他の工法と比較して多くの要 因の重要性が指摘されており、中でも落石や制離、 亀裂の有無、地表・地下水の有無、地表の土質、風 化状況等が重要な要因である。斜面安定工法 (Eと F）では、地表水・地下水の有無の重要性が高く、 力学的安定工法では地質の構造、支持地盤の有無、 さらには地滑りの可能性に対する要因が高くなって いる。

「工事の環境」では、植生工法が美観や工事中の 雨量・気温が、被覆工法では、作業スペース、美観、 工事の規模、安全・品質管理の重要性が指摘されて いる。また作業スペースに関しては植生工法を除く 全ての工法において重要な要因であることが分かる。

\section{3 意思決定ブロセスの構造化}

工法選択における意思決定のプロセスを明らかに するため、表一7に示した各要因每に実際の現場の 状況を記入してもらった。「地山の状況」について は、例えば”落石の有無”に関しては（1．かなり 有り、2.やや有り、3.なし、4.不明）、”地 表の土質” は（1. 硬岩、2. 軟岩、3.レキ質士、 4. 砂質土、5 . 粘性土）のように該当すると思わ れる番号に○を付けてをらうという方法を採用した ため、序数尺度と名義尺度のデータから構成されて いる。また「工事の環境」に関しては、全て序数尺 度のデータから構成されている（1．影響大、2． やや影響、 3 . 普通、4 .なし)。

分析のための手順は、以下の通りである。すなわ ち、始めに数量化理論第 3 類による構造分析。具体 的には、工法を5つに分類し（植生工法、被覆工法、 吹付け工法、地盤改良工法、力学的安定工法）、 「地山の状況」に関しては、”不明”のカテゴリを 除き、また「工事の環境」については、”なし”あ るいは”十分”を除いたカテゴリーを採用した。続 いて、クラスター分析による構造化。数量化理論第 3類により算出されたカテゴリーウエィト（第6成 分まで採用）に、クラスター分析を適用することに より、意思決定プロセスのグラフ化を行う（デンド ログラムの作成）。ここでクラスター分析の手法と しては、ウォード法を採用した。

このような手法を採用した理由は、表一 7 に示し た各要因が必ずしも独立している訳ではなく、各要 因間には何らかの相関関係があるため、要因間の関 連性を分析するための数量化理論の適用であり、ま たその結果を視覚的に表現する上でクラスター分析 用いた。これらの分析により、ある工法がどのよう な要因を重要視しているかが明らかとなる。

図一4は、「地山の状況」と各工法の関係を図示 したものである。図から以下のようなことが分かる。

（1）地盤改良工法は、地下水や地表水がある場合 に適用される工法である。すなわち、意思決定ルー ルとしては、排除ルールが適用されている。

（2）植生工法は地表水や地下水がなく、落石、龟 裂、冻離等むなく、地表の土質む砂質土や粘性土の 場合に使用可能であることが分かる。また、非常に 多くの要因を考慮する必要がある。このことは、こ 
れらの条件を満足しない場合には、植生工法が適用 出来ないことになる（排除ルール）。

（3）地表が岩質で亀裂がかなり有り、また勾配が

表 -7 斜面安定工法に係わる要因の重要度 (1) 地山の状況

\begin{tabular}{|c|c|c|c|c|c|c|c|}
\hline 要 & $\overline{\mathrm{A}}$ & $\overline{\mathrm{B}}$ & $\overline{\mathrm{C}}$ & D & $\bar{E}$ & $\bar{F}$ & $\bar{G}$ \\
\hline 1.落石の有無 & 0.577 & 0.233 & 0.919 & .000 & 0.001 & 0.075 & 0.095 \\
\hline 2. 制離の状況 & 0.146 & 0.250 & 0.988 & 0.441 & 0.023 & 0.147 & 0.202 \\
\hline 3. 龟裂の状況 & 0.068 & 0.206 & 0.775 & 0.366 & 0.093 & 0.204 & 0.383 \\
\hline 4. 侵食状況 & 0.177 & 0.117 & 0.386 & 0.299 & 0.094 & 0.063 & 0.038 \\
\hline 5.地表水の有無 & 0.643 & 0.304 & 0.818 & 0.462 & 0.700 & 0.419 & 0.079 \\
\hline 6. 地下水の有無 & 0.154 & 0.349 & 0.638 & 0.509 & 1.000 & 1.000 & 0.411 \\
\hline 7.地表の土質 & 1.000 & 0.525 & 0.849 & 0.526 & 0.446 & 0.688 & 0.351 \\
\hline 8.地表の風化状況 & 0.226 & 0.269 & 0.806 & 0.405 & 0.020 & 0.097 & 0.158 \\
\hline 9.地質の構造 & 0.154 & 0.343 & 0.492 & 0.320 & 0.580 & 0.853 & 1.000 \\
\hline 10 . 支持地盤 & 0.000 & 0.371 & 0.016 & 0.316 & 0.064 & 0.414 & 0.636 \\
\hline 11.勾配 & 0.714 & 1.000 & 1.000 & 0.990 & 0.402 & 0.531 & 0.536 \\
\hline 12. 地形 & 0.262 & 0.453 & 0.277 & 0.780 & 0.471 & 0.279 & 0.443 \\
\hline 13.のり高 & 0.260 & 0.567 & 0.490 & 0.555 & 0.175 & 0.290 & 0.341 \\
\hline 14. 地滑りの可能性 & 0.328 & 0.610 & 0.576 & 0.470 & 0.353 & 0.539 & 0.738 \\
\hline 15. その他 & 0.020 & 0.000 & 0.000 & 0.000 & 0.000 & 0.000 & 0.000 \\
\hline サンブル数 & 126 & 127 & 126 & 117 & 107 & 108 & 122 \\
\hline
\end{tabular}

(2) 工事の摆境

\begin{tabular}{|c|c|c|c|c|c|c|c|}
\hline 要 & A & B & $\underline{-}$ & D & $\underline{E}$ & $\mathrm{~F}$ & $\overline{\mathrm{G}}$ \\
\hline 般交通への影䇾 & 0.082 & 0.315 & 0.458 & 0.762 & 0.218 & 0.113 & \\
\hline 2. 周辺への騒音 & 0.020 & 0.085 & 0.174 & 0.053 & 0.109 & 0.101 & 0.190 \\
\hline 3.周逝への振動 & 0.011 & 0.015 & 000 & .021 & 0.100 & 0.078 & 0.186 \\
\hline 4 . 水質の污濁 & 0.050 & 0.036 & 0.231 & 0.086 & 0.475 & 0.698 & 0.051 \\
\hline 5.工事用進入路の制的 & 0.145 & 0.726 & 0.463 & 0.754 & 0.711 & 0.432 & 0.724 \\
\hline 6. 用地の碓保 & 0.065 & 0.380 & 0.295 & 0.380 & 0.419 & 0.159 & 0.402 \\
\hline 7.作業スペース & 0.129 & 1.000 & 0.806 & 1.000 & 1.000 & 0.933 & 1.000 \\
\hline 8. 専門的労初者の確保 & 0.077 & 0.571 & 0.459 & 0.381 & 0.398 & 0.261 & 0.424 \\
\hline 9.機械・材料の碓保 & 0.042 & 0.283 & 0.230 & 0.289 & 0.400 & 0.429 & 0.371 \\
\hline ᄃ期の制約 & 0.289 & 0.426 & 0.422 & 0.375 & 0.424 & 0.249 & 0.432 \\
\hline 11. 安全管理 & 0.170 & 0.720 & 0.912 & 0.680 & 0.331 & 0.336 & 0.570 \\
\hline 12. 弇質管理 & 0.4 & 0.767 & 1.000 & 0.359 & 0.568 & 1.000 & 0.492 \\
\hline 13. 維持管理 & 0.564 & 0.474 & 0.477 & 0.646 & 0.934 & 0.125 & 0.102 \\
\hline 14.美䚁 & 1.00 & 0.942 & 0.6 & 0.595 & 0.218 & 0.120 & 0.2 \\
\hline 15.斜面安定工事の規模 & 0.358 & 0.785 & 0.789 & 0.663 & 0.826 & 0.469 & 0.527 \\
\hline 16. I事中の雨量 & 0.717 & 0.344 & 0.611 & 0.358 & 0.787 & 0.502 & 0.154 \\
\hline - 工事中の気温 & 0.667 & 0.124 & 0.279 & 0.000 & 0.000 & 0.011 & 0.040 \\
\hline 18. その他 & 0.000 & 0.000 & 0.000 & 0.056 & 0.052 & 0.000 & 0.000 \\
\hline V媗 & 125 & 125 & 125 & 114 & 97 & 103 & 119 \\
\hline
\end{tabular}

$\mathrm{A}$ : 權生工法（斜面保護工法） B : 被覆工法 (斜面保護工法)

$\mathrm{C}$ : 吹き付け工法 (斜面保護工法) $\mathrm{D}$ ：その他の斜面保護工法

$\mathrm{E}$ : 排水工法（斜面安定工法） $\mathrm{F}$ : 地盤改良工法（斜面安定工法）

$\mathrm{G}$ : 力学的安定厂法
きつく、落石の可能性がある場合には、吹き付け工 法が最適である。

（4）被覆工法は、地表の風化がかなり進んでおり、 地滑り・落石の可能性が非常に大きく、切り土で、 のり高も高い場合に適用可能である。

（5）力学的安定工法は、斜面の安定勾 配が確保でき、支持地盤が有り、地滑り

・落石の可能性が有るような場所に適用 可能である。

以上、「地山の状況」と斜面安定工法 との関係を分析したが、工法により考虑 すべき要因が異なり、またその内容む大 きく違っている。これは工法の特性に基 づくものであるため、各工法の特徵と地 山の状況との関係を十分認識する必要が ある。

図-5は、「工事の環境」と各工法と の関連を分析した結果である。この結果 からむ各工法の特徽が読み取れるが、

「地山の状況」ほど明確な差は認められ ないが、力学的安定工法は、一般交通へ の影響が大であり、被覆工法は美観の考 虑や安全管理、品質管理、および工期の 制約を特に受ける工法であると認識され ていることが分かる。

以上の結果はあくまでむ 146 サンプ ルから得られた結果であるため、必ずし も十分なむのではないが、意思決定プロ

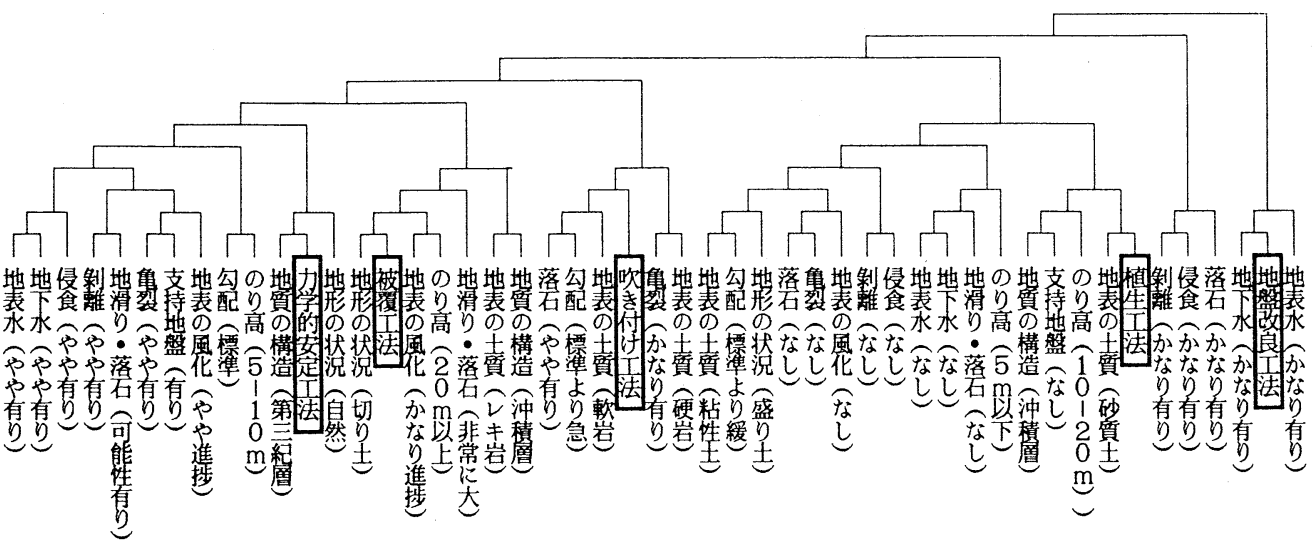

図-4「地山の状況」に関するデンドログラム 
セスとしては、非補償型のルールである排除ルール により、工法の絞り込みがなされているが、最終的 な工法選択においては補償型のルールも併用されて いると考えられる。このことをより明らかにするた め、数量化理論第 2 類を用いて直接的に工法の選択 構造を分析する。すなわち、外的基準として工法を、 また要因としては「地山の状況」と「工事の環境」 の各々の要因を用いた。したがって、この意思決定 基準は明らかに効用加算ルールに基づくものである。 数量化理論第 2 類の適用に当たっては、工法別に 得られたサンプル数には著しい偏りがあったため、 ここでは以下に示す 3 種類の工法のみによる分析を 行う。また 3 種類の工法別のサンプル数む十分な数 とは言えないため、ここで得られる結果は不十分な あのとなる。しかし、本研究の目的は意思決定プロ セスの構造化であり、工法選択モデルの作成ではな い。当然、最終的には工法選択モデルを作成する必 要があるが、その為にも意思決定プロセスの構造化 を明確にする必要性があるのは当然である。

表一9は、植生工法 (以下Aとする) 、被覆工法 (B)、および力学的安定工法 (G) の3 種類の工 法についての結果を表したものであり、表の数値は 数量化理論第 2 類によるレンジの值を示している （最大のレンジを 1 ．0として基準化してある）。 「地山の状況」では、3 種類の組み合わせについて 検討を行った。すなわち、 $\mathrm{A} 、 \mathrm{~B} 、 \mathrm{G}$ と外的基準を 3 のグループとした場合と、Aと B・GとA・B と Gのように2のグループとした場合について各々検
討を行った。その結果、相関比と的中率が最も高く なったのは、AとB・Gの2つのグループに分割し た場合である。これは、図ー4の結果からも明らか なように、被覆工法 (B) と力学的安定工法 (G) は、植生工法 (A) と比較して近い関係にあること からむ理解出来る。また、各要因のレンジの值から 地下水や地表水の有無、あるいは侵食状況や勾配の 状況が2つのグループの選別に大きな影響があるこ とが読み取れる。

次に「工事の環境」について同様の分析を行った 結果、被覆工法 (B) と力学的安定工法 (G) の分 割が最む的中率が高い結果となった。これらの関係 を図示すると結果的に図ー7のようになる。図ー7 は、「地山の状況」においては植生工法 (A) と被 覆工法 (B) ・力学的安定工法 (G) の2 分割が適 切であり、また「工事の環境」では被䚈工法 (B) と力学的安定工法 $(G)$ の分割を行うことにより、 3 種類の工法の選択を行うことが可能である。

このように意思決定が段階的に行われているとい うことは、工法により考虑すべき要因が異なり、ま た意思決定ルールむ単一ではなく、複数の意思決定 ルールが併用されていると理解することができる。 ただし、以上の分析は表ー4に示したように、大分 類のみの分析結果であり、実際には複数工法、ある いは小分類における工法の選択構造を明らかにする 必要があるが、本研究においてはサンプルデータの 不足により、この点については今後の課題としたい。

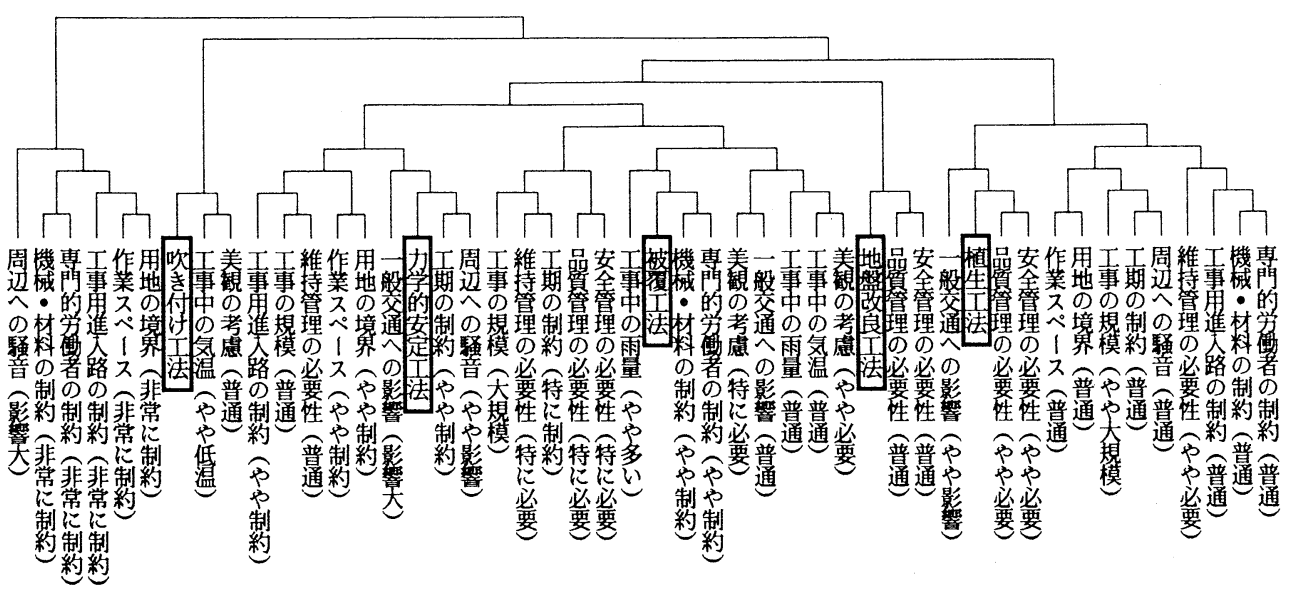

図-5「工事の環境」に関するデンドログラム 
表-9 数量化理論第 2 類による各要因のレンジ

\begin{tabular}{|c|l|c|}
\hline 記 号 & I 法 名 & サンプル数 \\
\hline $\mathrm{A}$ & 植生工法 & 26 \\
\hline $\mathrm{B}$ & 被覆工法 & 30 \\
\hline $\mathrm{G}$ & 力学的安定工法 & 51 \\
\hline
\end{tabular}

（1）地山の状況

\begin{tabular}{|c|c|c|c|}
\hline 要 因 & $A, B, G$ & $\overline{A, B G}$ & $\overline{\mathrm{AB}, \mathrm{G}}$ \\
\hline 落石の有無 & 0.619 & 0.483 & 0.701 \\
\hline 制碓の状涚 & 0.344 & 0.463 & 0.446 \\
\hline 龟裂の状況 & 0.165 & 0.334 & 0.179 \\
\hline 侵食状況 & 0.612 & 0.842 & 0.604 \\
\hline 地表水の有無 & 0.431 & 0.856 & 1.000 \\
\hline 地下水の有無 & 1.000 & 1.000 & 0.849 \\
\hline 地表の土質 & 0.613 & 0.665 & 0.479 \\
\hline 地表の㘣化状況 & 0.047 & 0.171 & 0.205 \\
\hline 地質の粠造 & 0.210 & 0.424 & 0.330 \\
\hline 支持地盤 & 0.314 & 0.327 & 0.299 \\
\hline 勾配 & 0.872 & 0.726 & 0.911 \\
\hline のり高 & 0.326 & 0.521 & 0.235 \\
\hline 地形 & 0.461 & 0.486 & 0.527 \\
\hline 地消り・落石の可能性 & 0.560 & 0.453 & 0.608 \\
\hline 相関比 & 0.615 & 0.578 & 0.537 \\
\hline 的中率 & $69.2 \%$ & $89.7 \%$ & $85.0 \%$ \\
\hline
\end{tabular}

(2) 工事の環境

\begin{tabular}{|c|c|c|c|c|}
\hline 要 因 & $A, B, G$ & $\overline{A B}, \mathrm{G}$ & $\overline{A, G}$ & $\overline{B, G}$ \\
\hline 一般交通への影鳘 & 0.083 & 0.071 & 0.506 & 0.554 \\
\hline 周辺への總音 & 0.953 & 0.948 & 0.593 & 1.000 \\
\hline 工事用進入路 & 0.335 & 0.316 & 0.107 & 0.509 \\
\hline 用地の境界 & 0.500 & 0.487 & 0.323 & 0.446 \\
\hline 作菜スペース & 0.352 & 0.360 & 0.505 & 0.223 \\
\hline 専門的労藓者 & 0.718 & 0.700 & 1.000 & 0.562 \\
\hline 機械・材料の制約 & 0.973 & 0.969 & 0.719 & 0.630 \\
\hline 工期の制約 & 0.582 & 0.580 & 0.706 & 0.704 \\
\hline 安全管理 & 0.161 & 0.165 & 0.443 & 0.260 \\
\hline 品貿管理 & 0.625 & 0.626 & 0.354 & 0.791 \\
\hline 維持管理 & 0.194 & 0.188 & 0.526 & 0.218 \\
\hline 美観 & 0.767 & 0.755 & 0.478 & 0.599 \\
\hline 斜面安定工事の規模 & 0.232 & 0.226 & 0.121 & 0.220 \\
\hline 工事中の雨㼂 & 0.600 & 0.575 & 0.231 & 0.677 \\
\hline 工事中の気温 & 1.000 & 1.000 & 0.975 & 0.758 \\
\hline 相蔺比 & 0.654 & 0.654 & 0.733 & 0.722 \\
\hline 的中率 & $63.2 \%$ & $90.6 \%$ & $96.1 \%$ & $97.5 \%$ \\
\hline
\end{tabular}

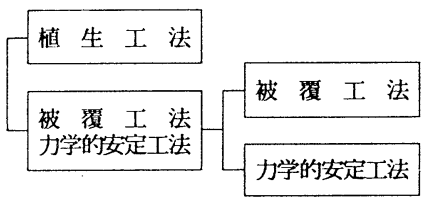

図一 7 段階的意思決定構造

\section{5. 結詥と今後の課題}

本研究は、建設工事における意思決定プロセスの 明確化を目的として実施したものであり、以下のよ うなことが明らかとなった。

（1）建設工事における意思決定のための要因の尺 度を整理し、複数の意思決定者から得られた順序デ 一夕を用いて、序列尺度から間隔尺度への変換方法 を提案した。
（2）建設工事における意思決定事例から、必ずし あ単一の意思決定ルールが採用されている訳ではな く、複数の意思決定ルールが併用されている。

（3）最終的に補償型の意思決定ルールが適用され ている場合です、その前段階においては非補傊型の ルールにより、選択肢の絞り込みが行われている。

(4) 斜面安定工事に関する実態調查結果から、単 独工法のみの適用は全体の $25 \%$ に過ぎず、残りの $75 \%$ 複数の工法の組み合わせとなっている。中 でむ、被覆工法と植生工法の組み合わせや力学的安 定工法と被覆工法の組み合わせが多い結果となった。 （5）意思決定のプロセスとしては、第 1 段階が選 択肢 (代替案) の絞り込みであり、第2 段階が総合 評価による選択肢の決定という構造を想定した。そ の結果、選択肢の絞り远み段階においては、非補償 型の意思決定ルールが、絵合評価の段階においては 補償型のルールが適用されているとの結論に達した が、必ずしむ十分に証明された訳ではない。この点 については、事例研究を通してさらに検討を行う必 要がある。

本研究を実施するに当たっては、建設マネジメン 卜委員会、計画・管理技法分科会に所属している委 員の皆様には多大なるご協力を得た。ここに記して 梁甚なる謝意を表す。

\section{参 考 文 献}

1) 石渡徳张 : マーケテイング モデル解析(1)、共立出版、 1990

2）利根薫：ゲーム感覚意思決定法、日科技連、1986

3) 吉井・林：建設工事におりる最適工法選定に関 する一考察、土木計画学研究・講演集、

№. 10, pp. $485-492,1987$

4) 斉藤参郎 : 正值逆比行列を用いた順序付き多肢 選択デー夕の比率尺度構成とその分解法、福岡大 学経済学論叢、Vol.33, No. 1, pp.1-45,1988

5 ) 守安 - 真砂 - 井上 : 選好強度付一対比較判断に 基づく基数効用値の同定、計測自動制御学会論文 集、Vol.23, No.2,pp.83-88, 1987

6 ）中村和弘：小口径推進における工法選定基準、 下水道協会誌、Vol.26, No. 299, pp. 47-63, 1989

7) 吉川・山田・日吉 : 路上表層再生工法の維持修 繥への適用について、建設省技術研究会報告、 Vol.40,pp. 553-557, 1986

8 ）佐藤・八谷・林：空港舗装の新しい修䋨設計方 法の開発、日加科学技術協議発表論文集「寒冷地 舗装」、Vol.2,pp. 203-219, 1984

9）奥園誠之：経験工学による斜面安定検討、第 5 回「施工体験発表会」講演概要、pp. 1-8, 1987 